\title{
1. Introduction to secession in Regional Politics and State Secession
}

State sovereignty is one of the foundational norms of the international system. Its significance is demonstrated by its articulation as a core principle in the United Nations (UN) Charter as well as the founding documents of most regional political organizations, including the African Union (AU), the European Union (EU), and the Arab League, among others. State secession violates a sovereign's territorial integrity in the most fundamental way and, perhaps not surprisingly, is a rare occurrence.

While most secessionist movements fail, some exceptional movements succeed in achieving internationally recognized statehood. However, it is not immediately clear why these particular movements should achieve statehood. Some of these newly created states look far less like states than many movements that have not achieved recognition. For example, Somaliland has had a functioning government for almost thirty years; it has free and fair elections, its own currency and flag, and even conducts limited foreign policy. Yet, despite its declaration of independence in 1991, the international community refuses to recognize it. South Sudan, on the other hand, emerged from Africa's longest running civil war in 2005 as one of the least developed areas on the continent, with no history of self-governance and no formal institutions. Yet, as of January 2011, South Sudan was universally recognized as the world's newest state and was quickly granted membership into the United Nations. So what accounts for the success of South Sudan and failure of Somaliland? Moreover, what can account for the success of any secessionist movement when so many fail? This book suggests that the answer can be found in regional politics.

This question has become increasingly important given the recent secessionist activity in Catalonia, the Kurdish Region in Iraq, and Kashmir, as well as the rising number of secessionist civil wars. These have increased by approximately thirty percent after 1945 compared to before (Fazal and Griffiths 2014). States are the most fundamental unit in international law and international relations, and yet there is so much ambiguity around how states become states and the role of international recognition in that process. As Bridget Coggins notes, 'Countries either exist or they do not, and how they come to be is presumed to be relatively unproblematic' (Coggins 2011, 435). ${ }^{1}$ 


\section{THE LEGAL LANDSCAPE}

International legal scholars have spent significantly more time than political scientists on the issue of state recognition, though a number of questions remain. Legal scholars often point to the Montevideo Convention on the Rights and Duties of States (1933) or the right to self-determination.

\section{a. Statehood and State Recognition}

The Montevideo Convention lays out four criteria for statehood. These include: (1) a defined territory; (2) a permanent population; (3) a functioning government; and (4) the ability to enter into foreign relations. Philip Jessup (then future judge on the International Court of Justice) referred to these when he stated in 1948, '[w]e are all aware that, under the traditional definition of the State in international law, all the great writers have pointed to four qualifications. ${ }^{2}$ Although the Montevideo Convention provides legal criteria for statehood, given that only states have the authority to recognize another state or withhold recognition, there is evidently a political dimension to recognition. Nonetheless, Lauterpacht expressed the view that when a political community has fulfilled the conditions for statehood prescribed by international law, states are under a duty to recognize the community as a state (Lauterpacht 1948). That is to say that states should base their recognition policy in international law, rather than their own strategic interests.

While three of the criteria under the Montevideo Convention (territory, population and government) are fairly straightforward, the final requirement does raise some questions. Does it refer to a current ability to enter into foreign relations, or the capacity for entering into foreign relations? A political community may have the capacity to enter into foreign relations if it has a functioning government. A current ability to enter into foreign relations usually requires that a political community have an international legal personality, that is, it must be internationally recognized as a state. ${ }^{3} \mathrm{Can}$ it be that one of the requirements to become a state is prior recognition as a state?

This leads to a debate over the nature of state recognition, essentially whether recognition is declaratory or constitutive. Declaratory theory provides that statehood exists prior to, and independent of, recognition (Brierly 1928 [1963], 140). The act of recognition is a formal acknowledgment of an established situation. According to constitutive theory, on the other hand, the very act of recognition creates statehood. While the declaratory theory seems to sidestep the problem posed by the political nature of recognition, recognition may not be so easy to ignore. Given the lack of supranational authority to determine whether a state exists, the legal consequences of statehood (for 
example, consular relations or membership in international organizations) simply will not attach if no state recognizes the political community as a state. While the Montevideo Convention's requirements may arguably be objective, the concept of statehood is nonetheless constructed. If the only entity that considers a particular political community to be a state is that particular political community itself, then it simply will not be able to engage with the rest of the international community as a state.

While the constitutive theory of recognition avoids this problem, it runs into other obstacles. What happens when a political community is recognized as a state by some states and not others? Is it a state or is it not a state? Is there some number of states that is necessary to weight the scales toward statehood? These problems remain unresolved.

Whichever theory one adopts, the matter of recognition is key. Under a declaratory theory, while a state may have the right to be treated as a state regardless of recognition, this right cannot be enjoyed until it is recognized by other states. As Oppenheim points out, 'recognition, while declaratory of an existing fact, is constitutive in its nature ... It marks the beginning of the effective enjoyment of the international rights and duties of the recognized community' (Jennings and Watts 1996, 133). ${ }^{4}$ Under a constitutive theory, a political community cannot be a state unless it is recognized.

\section{b. Self-Determination and Secession}

Legal scholars have written extensively on the right to secede, explaining if and when such a right should exist. Most legal arguments for the right to secession are based in the right to self-determination. President Woodrow Wilson first raised the international profile of self-determination when he included it in his Fourteen Points in 1916, stating 'every people has a right to choose the sovereignty under which they will live. ${ }^{5}$ The right to self-determination then found expression in the UN Charter, the Universal Declaration of Human Rights, and both of the most fundamental human rights treaties, the International Covenant on Civil and Political Rights and the International Covenant on Economic, Social, and Cultural Rights. Article 1 of both of these human rights treaties provides that the right to self-determination is the right of a 'people to freely determine their political status and pursue their economic, social and cultural development.' Although this right is codified, its articulation has created some ambiguity. Not only is it unclear who possesses this right, but there is also some debate over what this right entails. The right to self-determination vests in 'a people,' which has been left undefined in international law. The United Nations Educational, Scientific, and Cultural Organization (UNESCO) has provided a list of attributes that a group should fulfill all or some of to constitute a 'people.' These include a common historical tradition, racial or ethnic 
identity, cultural homogeneity, linguistic unity, religious or ideological affinity, territorial connection, and common economic life. Traditionally a two-part test has been applied. The first part is objective and looks to the attributes listed above. The second part is subjective and examines 'the extent to which individuals within the group self-consciously perceive themselves collectively as a distinct "people"" (Scharf 2003, 380).

The second point of contestation is whether it is appropriate to conflate the right to self-determination with the right to secession. Given the status of territorial integrity among international norms, secession is viewed with some wariness. As Ediberto Roman points out '[i]f each group within a state can claim the right to self-determination and succeed, self-destruction of virtually every state could result' (Roman 1999, 958-9). A number of scholars have attempted to clarify this area by distinguishing between internal and external self-determination. Internal self-determination refers to the protection of a people within a state through some level of autonomy and self-government. If a group can freely determine its political status and freely pursue its economic, social, and cultural development within the state, its right to self-determination will be deemed to have been met. (The right is one of process rather than outcome.) The right to internal self-determination applies to all peoples and although it is not always enjoyed, the right itself is not particularly controversial.

External self-determination, on the other hand, is essentially secession. To the extent that a right to external self-determination is said to exist, it is a right to what is known as 'remedial secession,' meaning that the right exists only to overcome an ongoing injustice (Buchanan 1997; Birch 1984; Borgen 2007). The parent state must be violating the human rights of the group seeking secession for this remedial right to exist, though there are varying views on the necessary severity of the human rights violation. According to Birch (1984), if a 'peoples' internal right to self-determination is not met, that right will evolve into a right to external self-determination.' According to Chandhoke (2012), the threshold is 'irrevocable institutionalized injustice,' while for Buchanan (1997), the violations must be such that they pose an existential threat to the group seeking secession. There is no consensus on the right to external self-determination. While the Canadian Supreme Court responded to Quebec's secessionist aspirations by noting, among other things, that the people of Quebec were not oppressed, implying the possibility for a remedial right to external self-determination, a number of prominent international lawyers deny its existence (Crawford 2000; Wildhaber 1995).

Not only is there current disagreement over how self-determination should be interpreted, but interpretations have also shifted over time. Today, secessionist movements often rely on self-determination arguments in their quest for secession, therefore, interpreting that right to include external self-determina- 
tion. A number of states, however (the United States included), understand the right to self-determination to be limited to an internal right. This is quite different from the circumstances around which discourse on self-determination took place in the early post-World War II period. The substance of the right to self-determination in the context of decolonization became quite clear. It meant statehood.

The UN General Assembly Resolution 1514 (1960) defined for the first time specific peoples who were deemed to be entitled to state sovereignty: the populations of non-self-governing and trust territories. Therefore, at that time, both the substance of the right to self-determination, and to whom it applied, were clear. The interpretation of self-determination as statehood in the context of decolonization side-stepped the preexisting legal theory of statehood altogether. In the context of decolonization, the four requirements of the Montevideo Convention were replaced with only one, that the population be one of a non-self-governing and trust territory.

Outside of the context of decolonization, the meaning of self-determination has become more fluid. ${ }^{6}$ The UN made this clear in 1961, where UN Security Council Resolution 169 affirmed Congo's territorial integrity and rejected Katanga's unilateral declaration of independence. In 1966, referring to the secession of Biafra from Nigeria, then Secretary-General U Thant stated that, 'the UN attitude is unequivocal. As an international organization, the UN has never accepted and does not accept and I do not believe it will ever accept the principle of secession of a part of its member state' (Nanda 1972, 327). Eight years after this statement, the UN admitted newly seceded Bangladesh into the organization. The inconsistency in approach to self-determination has led Christopher Borgen to refer to the trouble of conceptualizing self-determination in international law as 'a riddle, wrapped in a mystery, inside an enigma' (Borgen 2009, 6). While a number of international lawyers and scholars today have interpreted secession to be legally neutral, neither affirmatively permitted nor prohibited under international law (Pavkovic and Radan 2008), the international norms of state sovereignty and territorial integrity have caused most states to view secession with a certain degree of suspicion.

\section{THE POLITICAL LANDSCAPE}

Although numerous scholars focus on state secession, few focus specifically on the question of what determines whether a secessionist movement will achieve statehood. The literature generally addresses four areas, explaining: (1) the conditions under which secessionist movements emerge; (2) the variation in state responses to domestic movements; (3) the significance of the military strength of a movement and de facto statehood; and (4) the role 
of external actors. These are not entirely separate silos and some scholars combine a number of elements into their work.

Secessionist movements often engage in deadly civil wars and ultimately risk everything to become a recognized state. What motivates movements to take such drastic actions? There are two aspects to this motivation, the 'pull' factor, which relates to the attractive benefits of statehood in the international system today, and the 'push' factor, which relates to the specific domestic experiences of groups that lead them to want 'out.' The pull factors include a variety of economic, political, and security benefits. Economic benefits include access to various international financial institutions, foreign aid, and foreign markets and investors. Political benefits include greater access to political organizations, whether those are international or regional. Security benefits include the enjoyment of the protection of the norm against annexation. Most of the scholars in this area focus on what I have termed the push factors. These include explanations that focus on political grievances (Wimmer 2002; Gurr 2000; Bartkus 1999); economic concerns (Horowitz 1985; Hale 2008; Stewart 2009; Cederman et al. 2011); the role of diaspora communities (Heraclides 1990; Saideman 2001); the structure of the state (Bunce 1999; Roeder 2007; Smith 1991; Gurr 1993a) and the demography of the state (Toft 2002, 2003).

A significant amount of recent scholarship on secession addresses the variation in state responses to domestic secessionist movements, explaining the conditions under which states are likely to fight a movement or make concessions. Both Walter (2009) and Butt (2017) focus on the calculations a state makes about the risks associated with a secession. Walter points to the risk of setting a precedent for other potential movements. Therefore, the more potential secessionist movements in a state, the harder the state will fight to ensure a reputation that will deter others from making separatist demands. Butt focuses on a state's calculations about external threats. If war is likely (with either the seceded state or any other state) then a parent state will fight hard to deny a secession in order to prevent the negative shift in the balance of power that a secession would cause. If war is not anticipated, the parent state is more likely to make concessions.

Others pay closer attention to the internal structure of states and or movements to explain state responses. Cunningham (2014) looks at the number of factions within states and how unified or divided a separatist movement is. The more factions (up to a certain point) the more likely the state will make concessions. Cunningham also argues that states are more likely to make concessions to movements that are internally divided than those that are unified. Sorens (2012), on the other hand, looks at the consequences of state responses. He argues that the governments that have explicitly ruled out military suppression of democratic secession have experienced far less ethnic rebellion than governments who have firmly denied the possibility of separation. Griffiths 
(2016) bridges these different schools by focusing on both the state's fear of setting a precedent for other potential movements, and internal institutions. $\mathrm{He}$ argues that central governments use administrative lines and categories to determine the risks associated with denying demands or making concessions. Those areas that do not cohere with any administrative region are the least likely to be granted independence.

This body of work approaches secession on a spectrum. The concessions parent states will make largely fall short of independence. In some cases, secessionist movements are satisfied with greater autonomy within the confines of the parent state. In a way, this work is a precursor to this book. I do not focus on those movements that are satisfied with concessions short of independence, since they will no longer seek secession. Where a parent state concedes independence, the movement has found success. To the extent that this scholarship identifies those cases (where parent states are willing to make satisfactory concessions, be that independence or autonomy short of that), they can predict success for the movement. When the parent state is unwilling to make concessions and lose territory, a movement may or may not find success. In these cases, other factors come into play. This book focuses on these contested cases to explain that the most important factor in those cases is whether the movement has regional support.

While few scholars directly address the question of what it takes for a secessionist movement to achieve independence, it is often implicit in work addressing the military strength of a movement and de facto statehood. A number of scholars discuss attributes that make a secessionist movement strong, without necessarily relating strength to internationally recognized statehood.

The stronger a movement is militarily the more chance the movement has of establishing domestic authority within an area. If a movement has the coercive capacity to exclude any competing authorities within a territory, then a de facto state may exist. Some argue that de facto statehood cannot be ignored and will result in recognized statehood over time (Crawford 2000). One of the ways to increase military strength is to induce defections from the parent state's military. Horowitz (1985) looks to the ethnic composition of the military and the movement to explain when defections are most likely. Other scholars point to ethnicity in relation to the political structure of the state. Ethnically concentrated federations reinforce ethnic identity and facilitate ethnic mobilization and collective action. The relevant political community in this type of system often has enough self-governing capacity that it can easily imagine itself as an independent state (Siroky 2011; Fazal and Griffiths 2008; Roeder 1991; Bunce 1999). Not only may this type of political structure make secessionist sentiment more likely, but for those committed to independence, the self-governing structure a federation offers, facilitates steps toward de facto statehood. 
The significance of de facto statehood is underlined by those scholars that point to the importance to rebel groups of appearing 'state-like.' Stewart addresses the ways in which secessionist movements provide services to the entire population, rather than limiting benefits to their supporters, to legitimate their claims to sovereignty, while Huang looks at rebel diplomacy as a way for rebel groups to seek political capital and illustrate their state-like qualities (Stewart 2018; Huang 2016). Having state-like qualities and even achieving de facto statehood cannot explain existing variation in success across movements. Somaliland demonstrates that de facto statehood does not necessarily lead to international recognition.

The last significant body of literature addresses foreign support. A number of scholars focus on the response of the international community to secessionist movements (Osterud 1997; Saideman 2002; Fearon 2004). While some focus on the effect of international support on the demands of a movement (Kuperman 2008; Cetinyan 2002), most seek to explain the variation in external support, offering a number of motivations. Some point to the vulnerability of a state to secession within its own borders. To the extent that it faces threats at home, it will not support secessionist movements elsewhere (Zartman 1966; Jackson and Rosberg 1982; Englebert and Hummel 2005). Others point to ethnic ties to explain external support. This theory predicts that a state whose ruling elite has ethnic ties to the secessionists will support those secessions. It follows that if this elite has ethnic ties to the parent state, the external support will be for the parent state (Carment and James 1996; Saideman 1997). An institutional based theory points to the significance of regime type. Democracies have political values that lead them to oppose their mutual secessionist claims, while autocracies do not have the same constraints (Belanger and Paquin 2005). Finally, there are those that focus on strategic ties to explain support. Here various foreign policy objectives, including diplomatic relationships, regional stability, or access to markets or natural resources, motivate states to support secessions (Paquin 2010; Farkas 2003; Frombgen 1999; Sharafutdinova 2000). Ker-Lindsay (2012) adds a different perspective to this body of work through his focus on the foreign policy of states looking to counter secession, noting the significant role of external actors in ensuring the failure of a movement.

Finally, scholars point to foreign support to explain the success of secessionist movements. Given that statehood requires some international recognition, it is clear that actors beyond the parent state have a role to play. Secessionist movements are aware of the significance of external actors, and various scholars address ways in which movements intentionally appeal to actors beyond their state (Huang 2016; Stewart 2018). A number of scholars have noted that foreign support is necessary for successful secessions, without explaining the nature of the support or if it matters who provides it (Young 1994; Heraclides 
1991; Horowitz 1985). Very few scholars have explicitly made the argument that external actors determine whether secessions will happen and explained which actors are necessary. Both Sterio (2013) and Coggins (2011) explain secession through the interests of the great powers. Sterio argues that for a secessionist movement to succeed, it must meet four criteria, the most important of which is that it has garnered the support of the great powers (Sterio 2013). ${ }^{7}$ Riegl and Doboš (2017) have recently adapted Sterio's argument and suggested a 'modified (super)power rule,' which also emphasizes the role of the super power in the region. Coggins $(2011,2014)$ also emphasizes the role of great powers, though her research is limited to state recognition, and does not include other forms of interference and intervention. While not every member of the international community need recognize a state before it can be considered one, there must be a critical mass that does. According to Coggins, recognition by the great powers carries the greatest weight and has the greatest potential influence on others. 'Typically early movers, when the Great Powers agree, their decision serves as a focal point that initiates a cascade of legitimacy throughout the system's remaining members' (Coggins 2011, 449).

While great powers can be significant actors in secessions, Sterio's work has two limitations. The first is that it assumes that the great powers will have an interest in the outcome of every successful secession. Secessionist movements often emerge in parts of the world that are of very little geostrategic interest to any of the great powers. Little or limited great power support for a secession will not prevent a state from seceding. Ultimately the great powers are helpful but not absolutely necessary for a secession to occur. In the case of Bangladesh, the preference of the United States was for the territorial integrity of Pakistan. None of the other great powers had any particular interest in the outcome. Bangladesh, nonetheless, seceded from Pakistan.

Second, by focusing exclusively on the great powers, Sterio leaves unexplored the space between the emergence of a movement and great power support. Whether the movement survives in the short term, and how the conflict is framed to the international community, often has little to do with the great powers. As will be discussed below, my work complements that of Coggins.

\section{ARGUMENT}

Similar to both Coggins and Sterio, I argue that the role of external actors is determinative in the success of secessions. However, rather than focusing on the significance of the great powers, I focus on the role of regional actors. I argue that regional actors determine whether a secessionist movement will succeed in achieving internationally recognized statehood. Regional actors are so important because of their proximity to the secessionist movement. 
Regional actors' interests are more likely to be affected by developments within their region. Therefore, these states are more likely to have a stronger interest in the outcome and more incentive to take greater measures to effect a desirable outcome. Great powers can be unaffected by a secessionist struggle and may have no interest in the outcome. Low to no interest will unlikely translate into action.

I identify three mechanisms through which regional actors can determine the success or failure of a movement. These are: (1) providing tangible support to the movement or to the parent state to suppress a movement; (2) providing diplomatic support by framing the conflict and its resolution, and encouraging or discouraging the involvement of actors outside the region; and finally, (3) shaping great power foreign policy through their preferences and actions related to the outcome of a secessionist conflict.

Regional actors' proximity to a secessionist movement allows for more direct interference. Direct interference is easier for contiguous states, particularly if that support is intended to be clandestine. ${ }^{8}$ In terms of playing a diplomatic role, regional actors are often uniquely positioned to initiate negotiations between the parties and often act as gatekeepers between a secessionist movement and the international community, facilitating external support beyond the region, or obstructing it. They can provide a movement with legitimacy to the wider international community and, to the parties in conflict, they can frame international involvement in desirable or undesirable terms. Finally, a great power's decision to support a secession will be shaped by perceived consequences of the policy on the region, how it will affect its existing relationships in the region, as well as regional stability more generally.

Coggins' work is limited to state recognition and she makes a persuasive argument that the great powers are the most influential when it comes to being able to initiate a 'cascade of legitimacy' (Coggins 2011). However, great powers do not always have a particular interest in the outcome of a secession. Further, in cases where the great powers do have a preference, these will be affected by regional politics. They will balance their support of, or opposition to, a secession against their other interests in the region, namely regional stability or valuable relationships with regional actors. For this reason, one of the mechanisms through which regional actors can cause the success of a secession is through their ability to shape great power foreign policy.

This theory engages with the literature that focuses on the significance of external actors in secessions. It adds to much of the literature by arguing that external actors are necessary for success and also identifying which external actors are necessary. In response to the few scholars that have adopted this approach (Coggins 2014; Sterio 2013), I offer alternative actors, focusing on the significance of the region rather than the great powers. This argument also directly engages with the literature on international law, addressing the rela- 
tionship between the right to self-determination, the Montevideo Convention, norms on territorial integrity, and secession in practice.

While the body of literature on secession is vast, few scholars address the likelihood of a movement's success in terms of achieving statehood. Of those who do, none look to the role of actors in the region. Understanding regional actors' interests and policies will help explain whether a secessionist movement will achieve statehood. The implications of this argument are that international law and norms on statehood, territorial integrity, and self-determination have little to do with the success of a movement. Further, factors endogenous to a secessionist movement are significant in terms of its success only to the extent that those factors affect regional states' relationships with the movement. ${ }^{9}$ Lastly, understanding the preferences of regional actors is necessary to inform great power involvement in the secession, thus contributing to existing theories that rely on great powers to explain successful secessions.

Many secessionist struggles are deadly, protracted civil wars. Understanding whether a secessionist movement is likely to succeed (in achieving recognition) can inform predictions on the longevity of secessionist civil wars. For those involved in negotiating peace, it is critical to know which actors must buy into the process in order for it to have any lasting success. In the longer term, in an effort to avoid some of these secessionist wars, some type of framework for secession should be developed. In order to create a framework that has a chance of success, it is crucial to understand why secessions happen when they do, and who plays the most significant role in determining that outcome. This research suggests that efforts should begin with institutions at the regional level, rather than national or global.

\section{METHODOLOGY}

In this book I study the influence that regional actors have on state secession. My hypothesis is that the support of regional actors is the most important factor in successful secessions. I define successful secession as internationally recognized statehood, the clearest demonstration of which is membership into the UN. Although the UN does not itself confer recognition on a state, UN membership does reflect international opinion on recognition and is regarded as the 'gold standard' of international legitimacy (Ker-Lindsay 2012; Keating 2008).

To test this hypothesis, I rely on a comparative case study method. I have selected six cases across three geographical regions. I focus on the time period since 1945. The establishment of the UN, which codified state sovereignty and non-intervention, and outlawed war outside of very specific exceptions, makes this time period sufficiently different from the period before. ${ }^{10} \mathrm{I}$ have selected three regions, not only to test whether the success or failure of secession varies 
regionally but also to bolster the external validity of my findings. I focus on the regions where secessionist movements have been particularly active, the Horn of Africa, South Asia, and Europe.

While some scholars view decolonization as a form of secession (Coggins 2011; Griffiths 2016), I distinguish between the two. This project does not address decolonization movements. I view secession as the creation of new states, rather than the return to independence of formerly independent entities. As discussed above, the concept of external self-determination in the context of decolonization became clear in the 1960s. Given the change in the international community's attitude toward the legitimacy of colonization, self-determination movements within that context had a basis for statehood that became generally accepted. Outside of decolonization, self-determination movements seeking statehood have had much less success. Given the norm of state sovereignty and its corollary, territorial integrity, and the inability of these movements to rely on the norm against colonization, it is these cases that most interest me. Therefore, I have explicitly selected secessionist movements that are not fighting against a colonial power.

I also focus on contested secessions. Where a parent state easily concedes independence and is the first state to recognize a new entity, international recognition will immediately follow. Recognition in these cases does not violate state sovereignty and my claim about the significance of regional actors does not apply to those cases. However, what constitutes contested may not be immediately clear, since many secessions can be categorized as both contested and uncontested, depending on the snapshot in time. All secession attempts are likely to be contested on some level, as states will rarely, if ever, immediately acquiesce to demands for independence. Yet successful secessions will frequently be ultimately uncontested, since in most cases the parent state will eventually recognize the new entity. However, it would be misleading to categorize a case like South Sudan as an uncontested secession, when Sudan suffered through two secessionist civil wars lasting almost forty years before the Sudanese government accepted the results of a referendum on independence. By limiting my focus to cases where there is state sponsored violence against the movement and or movement supported violence against the state, I can isolate the cases where positions are entrenched and a secessionist movement and state cannot find a satisfactory solution on their own. It is in these cases where regional actors are key.

I have based my case selection on the 'most similar' method (Guerring 2007), selecting two cases in each region where there is variation in both my explanatory independent variable (regional support) and dependent variable (outcome). In the Horn of Africa, the cases are South Sudan and Somaliland. In South Sudan, there was a large degree of regional involvement and ultimate support for the secession. In Somaliland, however, there was little support for 
the secession, and, in fact, opposition among many of the regional actors. The cases in South Asia are Bangladesh and the Tamils in Sri Lanka. In South Asia, regional power India supported the secession of Bangladesh and ultimately opposed the secession of Tamil Eelam. In Europe, the cases are Slovenia and the Basque Country. Slovenia had the support of a number of regional actors, while the region has been opposed to a Basque secession.

Within each region, the cases are similar along other possible independent variables, including: the region itself, the strength of the movement's claims to statehood under the Montevideo Convention and the right to self-determination, as well as political factors, such as the military strength of a movement and the ethnic and political structure of the state. There are also similarities in terms of colonial histories (where relevant) and the causes of secessionist sentiment. In each case the secessionist movement faced a state that was unwilling to make concessions. Given that each pair of cases is in the same region, there is also no variation across the pool of potential state or institutional actors. Therefore, the layout of this book is three comparative case studies. I also have a comparative case study within Sudan. Using the 'before and after research design,' I compare South Sudan's first secessionist civil war (1956-1972) with its second (1982-2002) (George and Bennett 2005, 166-7).

While I have attempted to find as much similarity across potential independent variables within each region as possible, in some instances there is limited variation. In some cases, the variation is not problematic as it does not risk undermining the hypothesis. In fact, it may strengthen it. For example, regarding the military strength of a movement, the Tamil Tigers were significantly stronger vis-à-vis the Sri Lankan military than the Mukti Bahini were in relation to the Pakistani military. Given that the Tamils were unsuccessful and Bangladesh is an independent state, this variation does not question whether military strength should be an explanatory variable. However, in other cases, it is more problematic. For example, the successful Slovenian independence movement was militarily stronger than the failed Basques movement. I hope to overcome these issues by focusing on three comparative case studies, and, therefore, an issue raised by one comparison may be addressed by another.

In order to ensure that regional support is the key to explaining secessions and not another variable or combination of variables, I have employed process tracing. By going into some depth in each of the case studies I trace the processes linking regional support to secession. In each case I analyze regional actors' relationships with the secessionist movement and parent state through the three mechanisms discussed above. First, I determine whether the regional actor provided any material support or sanctuary to the movement, or whether it conspired with the parent state to suppress the movement. Second, I analyze regional actor involvement in any negotiating process between the movement and the parent state government, as well as whether the regional actor encour- 
aged or discouraged broader external involvement. Finally, I analyze great power involvement in the secession and that power's relationships with actors in the region.

Throughout this book I will demonstrate that competing explanations for the success of secessionist movements are inadequate. To that end, I address the strength of each movement's self-determination claims and whether each political community meets the Montevideo Convention's requirements for statehood. I then illustrate why the factors identified in the literature, for example, de facto statehood, the military strength of a movement, and the type of domestic institution, are inadequate. I pay special attention to the role of great powers in successful secessions, as it is this literature that I most closely associate with.

\section{PLAN OF BOOK}

The book proceeds as follows. Chapter 2 further elaborates my argument on the importance of regions. I explain the significance of regions in international politics and explain the mechanisms through which regional actors determine the outcomes of secessionist conflicts in some detail. I also address the role of regional institutions as an intervening variable in this argument.

Chapters 3 through 5 are empirical comparative case study chapters. Each chapter addresses a specific region. Chapter 3 focuses on South Asia, discussing and comparing the cases of Bangladesh and the Sri Lankan Tamils. Chapter 4 focuses on the Horn of Africa, discussing and comparing the cases of South Sudan and Somaliland. The case study on South Sudan also includes a within case comparison, contrasting Sudan's first secessionist attempt and civil war, with its second. Chapter 5 focuses on Europe, discussing and comparing the cases of Slovenia and the Basque Country in Spain.

Chapter 6 assesses the strength of the argument in light of the case studies and discusses the implications of this research for current movements, paying specific attention to the Kurds in Iraq and Catalonia. Finally, I identify further questions that this research raises.

\section{NOTES}

1. Some exceptions include: Coggins 2011, 2014 and Barkin and Cronin 1994.

2. UN Security Council 34d year, Official Records 383d Meeting 9-12 (1948).

3. There are some recent exceptions; for example, Somaliland has been able to enter into limited foreign relations and continues to be unrecognized.

4. UN membership has often been seen as 'proof' of statehood. While UN membership can be considered a proxy for statehood, the UN does not have the authority to grant or withhold state recognition. Only states have this authority. The UN can simply grant or withhold membership to the UN. As membership assumes 
statehood, UN membership is indicative of the prior recognition, or willingness to recognize, on the part of the states in the international community.

5. Woodrow Wilson's Address Before the League of Nations to Enforce Peace, May 27, 1916, reprinted in 53 CONG. REC. 8854 (May 29, 1916).

6. Given the fact that territorial borders for the most part remained the same during decolonization, many question whether these should really be considered secessions at all. As will be discussed, I distinguish between cases of decolonization and cases of secession, addressing only the latter.

7. The other criteria include a showing that the relevant people have been oppressed, the central government is relatively weak, and that it has been administered by some international organization or group.

8. Regional states do not have to be contiguous to the secessionist movement, although oftentimes they will be.

9. For example, the liberation movement in South Sudan adopted a Marxist ideology in the early 1980s, which appealed to the Marxist regime in Ethiopia, and led to greater Ethiopian support for the movement.

10. See Fazal and Griffiths (2014) for a discussion on how the U.S. enforcement of this norm changed the costs associated with secession. 